\title{
Interleukin-10 (IL-10) 1082 promoter polymorphisms and plasma IL-10 levels in patients with bacterial sepsis
}

\author{
MONICA CHAVEZ VIVAS ${ }^{1}$, HÉCTOR FABIO VILLAMARÍN-GUERRERO ${ }^{2}$, \\ CARLOS ALBERTO SANCHEZ ${ }^{3}$ \\ ${ }^{1}$ Department of Biomedical Sciences, Faculty of Health, Universidad Santiago de Cali, Colombia \\ ${ }^{2}$ Physical Therapy-ICU, Fundacion Valle del Lili, Cali, Colombia, \\ Grupo de investigación GIIMMEIN \\ ${ }^{3}$ Hospital Piloto de Popayan, Cauca, Colombia
}

\begin{abstract}
Background. Interleukin-10 (IL-10) is a multifunctional cytokine which has been seen to play a relevant role in the pathogenesis of sepsis. We examined the association between a single nucleotide polymorphism (SNP) in IL-10 -1082G/A in patients with sepsis in Cali city.

Methods. A total of 100 patients with sepsis and 50 control subjects were enrolled in this study. Blood samples were collected from all patients in EDTA containing tubes. IL-10-1082G/A gene promoter polymorphism was analyzed by Sequence Specific Polymerase Chain Reaction (SS-PCR), while levels of serum IL-10 were measured by Enzyme Linked Immunoassay Assay (ELISA) in patients with sepsis and healthy controls.

Results. AA homozygous genotype was found more frequently in patients (32\%), compared with controls (18\%). AA homozygous patients showed an increased risk of developing infection by Gram-negative bacteria $(\mathrm{OR}=2,875 ; 95 \% \mathrm{CI}=1.162-7.113 ; \mathrm{p}=0.020)$, and significantly high plasma levels of IL-10 $(\mathrm{OR}=4.800,95 \%$ CI 1.652-13.944; $\mathrm{p}=0.002)$. AA homozygous patients high plasma IL-10 levels have greater risk of developing sepsis $(63.6 \%$; OR $=4,894 ; 95 \%$ CI: $1,337-17,909$; $\mathrm{p}=0.002)$. In this group, Afro-Colombian individuals were overrepresented among the sepsis patients with high plasma IL-10 levels $(\mathrm{OR}=1.661 ; 95 \% \mathrm{CI}: 1.408-1.959 ; \mathrm{p}=0.036)$.

Conclusion. Our study concluded that AA genotype of IL-10 -1082G/A polymorphism is a risk factor for high IL-10 production and development of sepsis by Gram negative bacteria, especially in Afro-Colombian patients.
\end{abstract}

Key words: Interleukin-10, single nucleotide polymorphism, SNPs, genotype, sepsis, septic shock.

\section{INTRODUCTION}

Interleukin-10 (IL-10) is a cytokine whose main function is to limit the inflammatory response. Infections are one of the factors that influence its production [1], and it has been seen to play a relevant role in the pathogenesis of sepsis [2]. In this sense, excessive production of Interleukin-10 has been related as an inducer of immunosuppression in bacterial sepsis and increased mortality [3].

On the other hand, it has been established that the risk of suffering septic shock is related to the increase in plasma concentrations of IL-10 [4, 5].

The production of this cytokine varies between individuals and is influenced by genetic characteristics, including single nucleotide polymorphisms (SNPs) within the IL-10 gene. Accumulating researches reported three SNPs presents in the promotor region of IL-10 $(-1082$, -819 , and -592 ) that have been related to changes in IL-10 levels and in the susceptibility of sepsis $[4,6]$.
The SNP A/G-1082 is related with the outcome of sepsis [4, 7]. However, Shu et al. reported that may be associated with susceptibility to severe sepsis, but not to the evolution of severe sepsis [8].

The $-1082 \mathrm{~A}$ allele is related to susceptibility to the development of sepsis; the AA genotype being related to an increase in the production of IL-10 and, therefore, with immunosuppression induced by infections. The GG genotype has been associated with lower mortality in patients who develop sepsis [7]. Contradictory results have been found in other investigations, the $-1082 \mathrm{~A}$ allele is significantly associated with lower production of IL-10 induced due to the effect of lipopolysaccharide (LPS) of Gram negative bacteria and the $-1082 \mathrm{G}$ allele is related to a higher IL-10 production and higher mortality in severe sepsis $[9,10]$.

Studies in this polymorphism are necessary to evaluate the precision of these data in different populations, since early diagnosis of the disease 
and correct compliance with clinical support play a critical role in mortality. The objective of this study was to evaluate the $-1082 \mathrm{~A} / \mathrm{G}$ porlimorphism of the promoter region of the IL-10 gene in septic patients from a Intensive Care Units of Colombia.

\section{MATERIALS AND METHODS}

\section{Patients}

A total of 100 (44 females, and 56 males) samples derived from patients with sepsis from a Intensive Care Units of Colombia between March to November 2017.

The inclusion criteria were: patients who are in the Intensive Care Unit with a diagnosis of bacterial sepsis, over 18 years of age and who signed the informed consent. Sepsis diagnosis was defined by standard criteria [11].

The patients included in the studies represented the following ethnic groups: AfroColombian population (for individuals of mixed Amerindian and black ancestry), Amerindian population (or Indigenous ethnic groups), and nonethnic population (consisting of whites, mestizos and castizos).

Patients were excluded if they met with the following: infected with the human immunodeficiency virus (HIV), pregnancy, therapeutic use of cytokines, heparin or thrombolytics, antibiotics treatment prior to admission, and patients who did not survive more than 24 hours.

Fifty from individuals who were identified as at-risk patients who did not meet criteria for sepsis during the ICU stay and had no prior history of sepsis were enrolled as controls. This study was conducted in accordance with the Helsinki Declaration and approved by the hospital Medical Ethics Committee (Act No. 05-013). All patients (or their legal representatives) were sufficiently informed about goals and procedures. Samples and data were obtained after written informed consent was signed.

\section{Determination of IL-10 in plasma}

Venous blood samples for the determination of plasma levels of IL-10 were obtained at admission and at 48 hours after admission in the ICU.

Blood was collected by venipuncture into $15-\mathrm{ml}$ sterile vacutainers either containing EDTA $(10 \mathrm{mmol} / \mathrm{L})$ as anticoagulant. The tubes were centrifuged immediately for ten minutes at 3,000 rpm, and the plasma was stored in aliquots at $-70^{\circ} \mathrm{C}$. The remaining blood was used to DNA extraction.

The analysis of IL-10 was performed using an enzyme immunoassay with Human ELISA kit (Elabscience Biotechnology Inc. USA) following manufactures' instructions. The detection range was $7.81-500 \mathrm{pg} / \mathrm{mL}$, with intra and interassay coefficients of variation below 5\%. Readings were carried out in an automated optical Spectramax reader at $450 \mathrm{~nm}$. The sensitivity of the assay was $<2 \mathrm{pg} / \mathrm{mL}$.

\section{DNA extraction}

Total genomic DNA was extracted from 2-ml blood of each sample using DNeasy Blood \& Tissue Kit (Cat No. 69506 QIAGEN) following the protocol established by the commercial Company and then stored at $-70^{\circ} \mathrm{C}$. To assess the DNA quality after DNA extraction, the $\beta$-globin gene amplification was used in all extracted samples. The concentration of DNA in the samples was quantified by using a FOTO/Analyst ${ }^{\circledR}$ Investigator/FX Systems (FOTODYNE Incorporated).

Genotyping of the gene encoding IL-10 $(-1082 \mathrm{G} / \mathrm{A})$ was carried out using the sequence Specific Polymerase Chain Reaction assay (SSPCR), which consists of using the primers with the polymorphism $-1082 \mathrm{G}$ for allele $\mathrm{G}$ and $-1082 \mathrm{~A}$ for allele $\mathrm{A}$ with the following amplification conditions: one cycle at $95^{\circ} \mathrm{C}$ for $5 \mathrm{~min}$ followed by 30 cycles at $95^{\circ} \mathrm{C}$ for $1 \mathrm{~min}, 60^{\circ} \mathrm{C}$ for $1 \mathrm{~min}, 72^{\circ} \mathrm{C}$ for $1 \mathrm{~min}$ and finally for $10 \mathrm{~min}$ extension at $72^{\circ} \mathrm{C}$. The generic IL-10 primers 5'-TCT CGG TTT CTT CTC CAT CG-3', allele primer G 5'-ATA GGT TTT GAG GGG CAT GG-3' and allele primer A 5'-ATA GGT TTT GAGGGG CAT GA-3' - Amplification was carried out using the Bio-Rad thermocycler.

The electrophoresis of the PCR products was carried out on $2 \%$ agarose gel and visualized by Syber Green (Fisher Scientific Inc.Madrid). The presence or absence of fragments was visualized by means of a UV transilluminator. A product size of $161 \mathrm{bp}$ was considered a positive amplification. Each of the primer mixes contained a pair of control primers that amplified a portion of the human $\beta$-globin gene.

\section{Statistical analysis}

Frequencies of the genotypes, alleles, and phenotypes were analyzed by Chi-square test. 
Continuous variables are expressed as mean \pm SD and categorical variables as frequencies and percentages (\%). For non-normally distributed variables median and $25^{\text {th }}-75^{\text {th }}$ percentiles were used.

Regression analysis was employed to analyze the association between the studied SNPs and the risk of sepsis. The clinical impact for the predictor variables was calculated by odds ratio (OR) and $95 \%$ confidence intervals (CI). Homozygotes of the most frequent genotypes were used as a reference group. We plotted survival curves of patient groups with AA, AG and GG genotypes using the KaplanMeier method. We tested the Hardy-Weinberg equilibrium in the genotypes using the Chi-square test. P-values of less than 0.05 were considered statistically significant. SPSS ${ }^{\circledR}$ statistical package, version 26.0 (SPSS Inc., Chicago, IL, USA) for Windows ${ }^{\circledR}$ were used for statistical analyses.

\section{RESULTS}

The mean age of patients with sepsis was 53 years ( $\mathrm{SD} \pm 18,880)$, SOFA index of 89 ( $\mathrm{SD} \pm$ $0.945)$ and 7 days $(\mathrm{SD} \pm 4.874)$ of hospital stay. The mean age of the control group ( 89 females and 21 males) was 39.4 years ( $\mathrm{SD} \pm 11.95)$.

In this study, $68 \%$ of the patients presented sepsis and $32 \%$ septic shock. The most frequently isolated etiologic agent was Gram negative bacteria $(55 \% ; \mathrm{p}<0.05)$. The ICU mortality rate was $13 \%$. Septic shock was more frequent among non-survivors than survivors $(61.5 \%$ vs. $27.6 \%$, $\mathrm{p}<0.05)$. We do not find statistically significant differences between patient groups in sex, age, ethnicity coexisting diseases (hypertension, diabetes mellitus, coronary artery disease, chronic obstructive pulmonary disease [COPD], malignancy), primary site of infection, evolving organ dysfunction, and outcomes of sepsis.

Genotypes and alleles in IL-10 promoter polymorphism $(-1082 \mathrm{~A} / \mathrm{G})$. The frequencies of genotypes and alleles of IL-10 polymorphisms according to the characteristics of the patients are presented in Table 1. Analysis indicated a predominance of the A allele with a frequency of $85 \%$, compared to the $\mathrm{G}$ allele $(66 \%)$.

The AG heterozygous genotype was found more frequently in patients with sepsis $(35 \%)$ and septic shock (16\%), followed by the AA homozygous genotype with $22 \%$ and $11 \%$, respectively.
Genotype frequencies in both patients and controls were in accordance with the Hardy-Weinberg equilibrium $(p>0.05)$. As shown in Table 2, frequency of AG (56\%) and GG (26\%) genotypes were found more frequently in healthy individuals. While that AA homozygous genotype was found more frequently in patients (32\%), compared with controls (18\%). Although GG genotype occurred only in control group with a frequency of $26 \%$, no significant differences were found in the frequencies of genotypes between septic patients and the control group at this position $(\mathrm{p}=0.26)$.

None of the genotypes was representative for patients with an ICU hospital stay of more than 7 days.

\section{IL-10 serum level}

The median plasma levels of IL-10 in patients with sepsis at admission and at 48 hours after admission in the ICU were 43.00 [26.5-72.5] $\mathrm{pg} / \mathrm{mL}$ and 45 [30-69] $\mathrm{pg} / \mathrm{mL}$, respectively. In healthy individuals, median plasma levels of IL-10 was $8.00[7,50-9,63] \mathrm{pg} / \mathrm{mL}$ values above these were considered high. Patients with high plasma levels of $1 \mathrm{~L}-10$ represented $63 \%$.

We found that $44.4 \%$ patients with genotype AG, $42.9 \%$ with AA genotypes and $11.1 \%$ GG genotypes showed high plasma IL-10 levels (Table 2). However, AA homozygous patients showed higher plasma IL-10 levels than patients with genotypes $\mathrm{GG}(\mathrm{p}=0.002)$ or $\mathrm{AG}(\mathrm{p}=0.002)$, and patients with genotypes AG showed higher plasma IL-10 levels than patients with genotypes GG $(\mathrm{p}=0.040)($ Figure 1).

On regression analysis, AA homozygous patients showed had a 2.875-fold increased risk of developing infection by Gram-negative bacteria $(\mathrm{OR}=2.875 ; 95 \% \mathrm{CI}=1.162-7.113 ; \mathrm{p}=0.020)$, and showed significantly high plasma levels of IL-10 $(\mathrm{OR}=4.800 ; 95 \%$ CI 1.652-13.944; $\mathrm{p}=0.002)$.

In addition, we found that AA homozygous patients high plasma IL-10 levels have greater risk of developing sepsis $(63.6 \%$; OR $=4.894 ; 95 \% \mathrm{CI}$ : 1,337-17.909; $p=0.002$ ) (Tables 2 and 3). On the other hand, Afro-Colombian patients with AA genotype were overrepresented among the sepsis patients with high plasma IL-10 levels at admission in the ICU $(\mathrm{OR}=1.661 ; 95 \% \mathrm{CI}$ : $1.408-1.959$; $\mathrm{p}=0.036$ ), and at 48 hours after admission $(\mathrm{OR}=1.525 ; 95 \% \mathrm{CI}: 01.316-1.766 ; \mathrm{p}=0.060)$. 
Table 1

Characteristics of septic patients according to genotype of IL-10 promoter polymorphism $(-1082 \mathrm{~A} / \mathrm{G})$

\begin{tabular}{|c|c|c|c|c|c|}
\hline Characteristic & $\begin{array}{c}\text { Total } \\
(\mathrm{n}=\mathbf{1 0 0})\end{array}$ & $\begin{array}{c}\mathbf{A G} / \mathbf{G G} \\
\mathrm{n}=\mathbf{6 8} \\
\mathrm{n}(\%)\end{array}$ & $\begin{array}{c}\mathbf{A A} \mathbf{n}=32 \\
\text { n (\%) }\end{array}$ & OR $(95 \% \mathrm{CI})$ & P-value \\
\hline \multicolumn{6}{|c|}{ Gender } \\
\hline Female & $25(40.3)$ & $31(44.1)$ & $11(34.4)$ & $0.625(0.261-1.495)$ & 0.427 \\
\hline Male & $37(59.7)$ & $37(54.4)$ & $21(65.6)$ & & \\
\hline \multicolumn{6}{|c|}{ Ethnicity } \\
\hline non-ethnic & 41 & $29(42.6)$ & $12(37.5)$ & $0.807(0.34-1.19)$ & 0.625 \\
\hline Afro-Colombian & 40 & 30 (44.1) & $10(31.3$ & & \\
\hline Amerindian & 19 & $9(13.2)$ & $10(31.3)$ & & \\
\hline \multicolumn{6}{|c|}{ Primary site of infection } \\
\hline Lung & 32 & $25(37.8)$ & $7(21.9)$ & $0.482(0.182-1.273)$ & 0.136 \\
\hline Urinary tract & 19 & $15(22.1)$ & $4(12.5)$ & $0.505(0.153-1.666)$ & 0.256 \\
\hline Abdomen & 25 & $15(22.1)$ & $10(21.3)$ & $1.606(0.626-4.120)$ & 0.322 \\
\hline Soft tissue infections & 5 & $3(4.4)$ & $2(6.3)$ & $1.444(0.229-9.102)$ & 0.694 \\
\hline Unknown foci & 6 & $3(4.4)$ & $3(9.4)$ & $2.241(0.427-11.777)$ & 0.330 \\
\hline \multicolumn{6}{|c|}{ Coexisting diseases } \\
\hline Hypertension & 42 & $26(38.2)$ & $16(50)$ & $1.615(0.692-3.773)$ & 0.266 \\
\hline Diabetes mellitus & 29 & $16(23.5)$ & $13(40.6)$ & $2.224(0.903-5.474)$ & 0.079 \\
\hline Coronary artery disease & 15 & $12(17.6)$ & $3(9.4)$ & $0.483(0.126-1.848)$ & 0.280 \\
\hline Malignancy & 3 & $3(4.4)$ & 0 & $1.046(0.994-1.101)$ & 0.228 \\
\hline COPD & 21 & $14(20.6)$ & $7(21.9)$ & $1.080(0 ., 388-3.006)$ & 0.883 \\
\hline Liver disease & 12 & $9(13.2)$ & $3(9.4)$ & $0.678(0.171-2.696)$ & 0.579 \\
\hline Neurological disease & 8 & $3(4.4)$ & $5(15.6)$ & $4.012(0.895-17.983)$ & 0.054 \\
\hline \multicolumn{6}{|c|}{ Evolving organ dysfunction } \\
\hline Acute renal failure & 15 & $8(11.8)$ & $7(21.9)$ & $2.100(0.688-6.414)$ & 0.187 \\
\hline Respiratory failure & 11 & $9(13.2)$ & $2(6.3)$ & $0.437(0.089-2.152)$ & 0.298 \\
\hline Haematological process & 11 & $7(10.3)$ & $4(12.5)$ & $3.095(0.650-14.746)$ & 0.139 \\
\hline \multicolumn{6}{|c|}{ Microbes } \\
\hline Gram-positive bacteria & 9 & $9(13.2)$ & 0 & $1,153(1.001 .265)$ & 0,031 \\
\hline Gram-negative bacteria & 55 & $32(47.1)$ & $23(71.2)$ & $2.875(1.162-7.113)$ & 0.02 \\
\hline Unidentified bacteria & 49 & $29(42.6)$ & $12(37.5)$ & $0.807(0.341-1.911)$ & 0.625 \\
\hline \multicolumn{6}{|c|}{ Outcomes } \\
\hline Sepsis & 68 & $46(67.6)$ & $22(32.4)$ & $0.853(0.349-2.083)$ & 0.727 \\
\hline Shock septic & 32 & $19(59.4)$ & $11(34.4)$ & & \\
\hline Non-survivors & 13 & $8(11.2)$ & $5(40.6)$ & $1.389(0.416-4.640)$ & 0.592 \\
\hline Survivors & 87 & $60(88.2)$ & $27(84.4)$ & $1.239(0.582-2.638)$ & 0.592 \\
\hline
\end{tabular}

$\mathrm{COPD}=$ chronic obstructive pulmonary disease; $*$ significant difference, $\mathrm{P}<0.05 ;{ }^{\psi}$ Only in survivors.

\section{Table 2}

Distribution of IL-10 promoter polymorphism $(-1082 \mathrm{~A} / \mathrm{G})$ in patients with sepsis and septic shock, with IL-10 - high, non-survivors, with length of ICU stay $>7$ days and healthy controls

\begin{tabular}{|c|c|c|c|c|c|c|}
\hline Variables & $\begin{array}{c}\text { Sepsis/septic } \\
\text { shock } \\
\text { n = 68/32 }(\%)\end{array}$ & $\begin{array}{c}\text { Non-survivors } \\
\text { n }(\%)\end{array}$ & $\begin{array}{l}\text { IL-10 - High } \\
\text { admission } \\
\text { n (\%) }\end{array}$ & $\begin{array}{l}\text { IL-10 - High } \\
\text { at } 48 \text { hrs. } \\
\text { n (\%) }\end{array}$ & $\begin{array}{l}\text { Stay }>7 \text { days } \\
\text { n }(\%)\end{array}$ & $\begin{array}{c}\text { Healthy controls } \\
(\mathbf{n}=\mathbf{5 0}) \\
\mathrm{n}(\%)\end{array}$ \\
\hline \multicolumn{7}{|c|}{ Allele } \\
\hline G & $46 / 19(65)$ & $7(53.8)$ & $35(55.6)^{1}$ & $40\{58.8)$ & $32(50.8)$ & $42(84)$ \\
\hline A & $57 / 29(86)$ & & & \\
\hline AA & $22 / 11(33)$ & $5(38.1)$ & $\begin{array}{l}\text { Genotype } \\
27(42.9)^{2}\end{array}$ & $27(39.7)^{3}$ & $22(34.9)$ & $9(18)$ \\
\hline AG & $35 / 16(51)$ & $4(30.8)$ & $28(44.4)$ & $33(48.5)$ & $29(46)$ & $28(56)$ \\
\hline GG & $11 / 3(14)$ & $3(23.1)$ & $7(11.1)$ & $7(10.3)$ & $11(17.5)$ & $13(26)$ \\
\hline
\end{tabular}

$\mathrm{T} \mathrm{OR}=0.64,95 \%$ CI $0.49-0.85 ; \mathrm{p}=0.004$

${ }^{2} \mathrm{OR}=4.800,95 \%$ CI $1.652-13.944 ; \mathrm{p}=0.002$

${ }^{3} \mathrm{OR}=1.40,95 \%$ CI $1.10-1.79 ; \mathrm{p}=0.016$ 


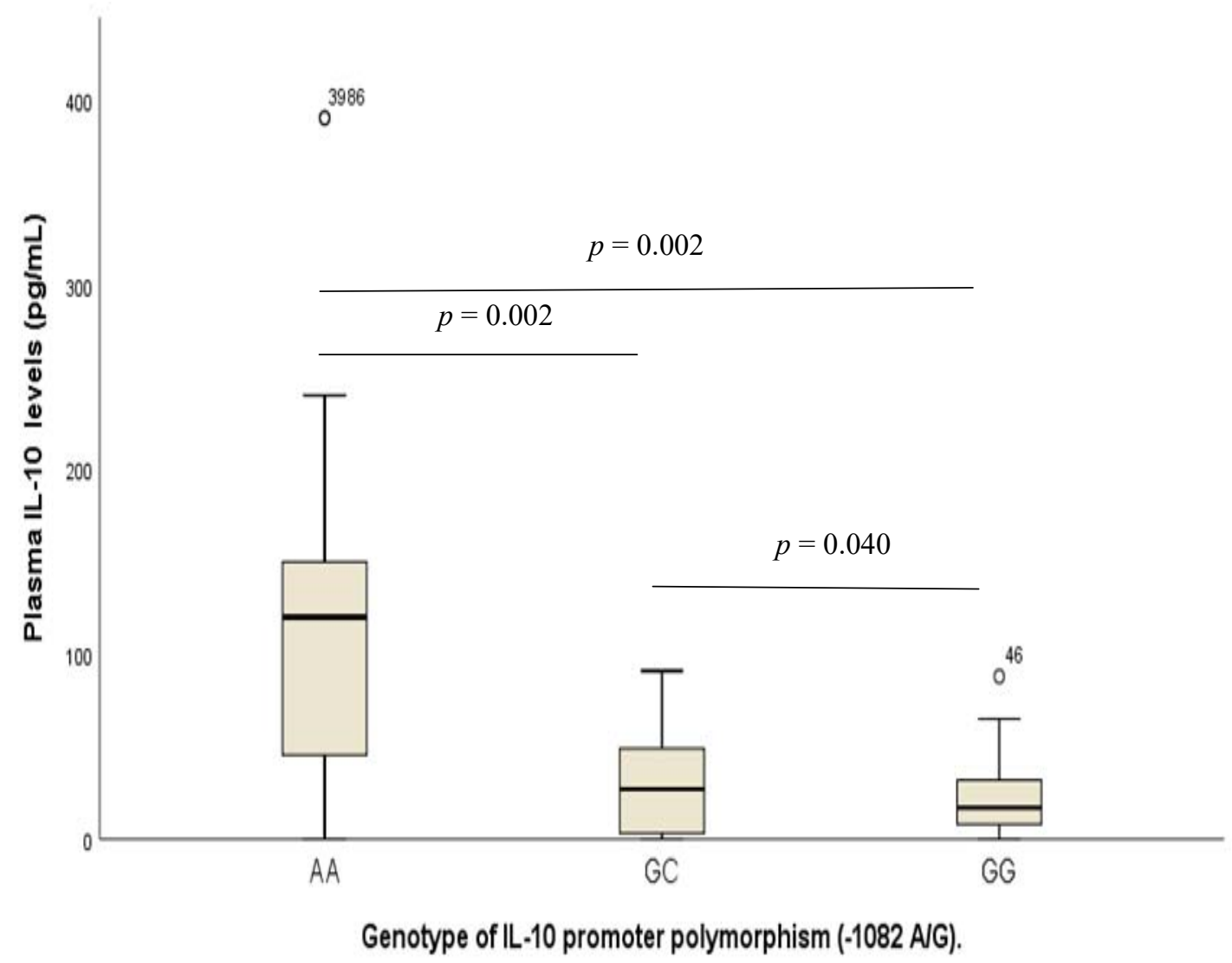

Figure 1. Plasma interleukin-10 levels according to the genotype of IL-10 promoter polymorphism (-1082 A/G).

Table 3

Association analysis of genotypes in IL-10 promoter polymorphism $(-1082 \mathrm{~A} / \mathrm{G})$ with high plasma levels of IL-10 and the development of sepsis and ethnicity

\begin{tabular}{ccccc}
\hline \multirow{2}{*}{ Patients } & \multicolumn{3}{c}{ Genotype } \\
\cline { 2 - 5 } & AA n = 22 & GG/AG n = 78 & OR \\
Sepsis & $14(63.6)$ & IL-10 - High admission & $\mathbf{0 . 0 1 0}$ \\
Sepsis - Non-ethnic & $8(36.4)$ & $55(70.5)$ & $2.545(0.511-12.689)$ & 0.241 \\
Sepsis - Afro-Colombian & $7(31.8)$ & $56(71.8)$ & $1.661(1.408-1.959)$ & $\mathbf{0 . 0 3 6}$ \\
Sepsis - Amerindian & $7(31.8)$ & $56(71.8)$ & $4.500(0.531-38.122)$ & 0.135 \\
& $18(81.8)$ & $50(64.1)$ & $2.520(0.776-8.185)$ & 0.116 \\
Sepsis & $10(45.5)$ & $58(74.4)$ & $0.931(0.290-2.990)$ & 0.904 \\
Sepsis - Non-ethnic & $7(31.8)$ & $61(78.2)$ & $1.525(01.316-1.766)$ & $\mathbf{0 . 0 6 0}$ \\
Sepsis - Afro-Colombian & $7(31.8)$ & $61(78.2)$ & $3.557(0.419-30.218)$ & 0.218 \\
Sepsis - Amerindian & & &
\end{tabular}

Patients with septic shock did not show a significant association with genotypes, ethnic group, or plasma levels of IL- 10 .

On the other hand, individuals with $\mathrm{G}$ allele showed lower plasma IL-10 levels than those with A allele (OR $=0.64 ; 95 \%$ CI: $0.49-0.85 ; \mathrm{p}=0.004)$.

Kaplan-Meier analysis did not show differences in mortality between different genotypes $(p=0.281)$ (Figure 2).

\section{DISCUSSION}

Sepsis is a complex immune response due to invasive infection, in which a prolonged and profound state of immunosuppression occurs. Hence, increased anti-inflammatory cytokines (eg IL-10) is one of the main features during immunosuppression in sepsis [12].

Previous studies showed that polymorphism in the regulatory region of the IL-10 gene may influence 
its expression, and susceptibility to developing sepsis $[5,6,9,13,14]$.

In the present study, we found that patients with AA homozygous in IL-10 promoter polymorphism $(-1082 \mathrm{~A} / \mathrm{G})$ are associated with high plasma levels of IL-10. Kang et al. reported that the poly
ADP-ribose polymerase 1 (PARP-1) acts in the regulation of IL-10 production in an $1082 \mathrm{G}>$ A allelesdependent, which determines individual susceptibility to sepsis [15]. Schaaf et al. demonstrated in their studies, over-expression of IL10 induce immunosuppression in bacterial sepsis [10].

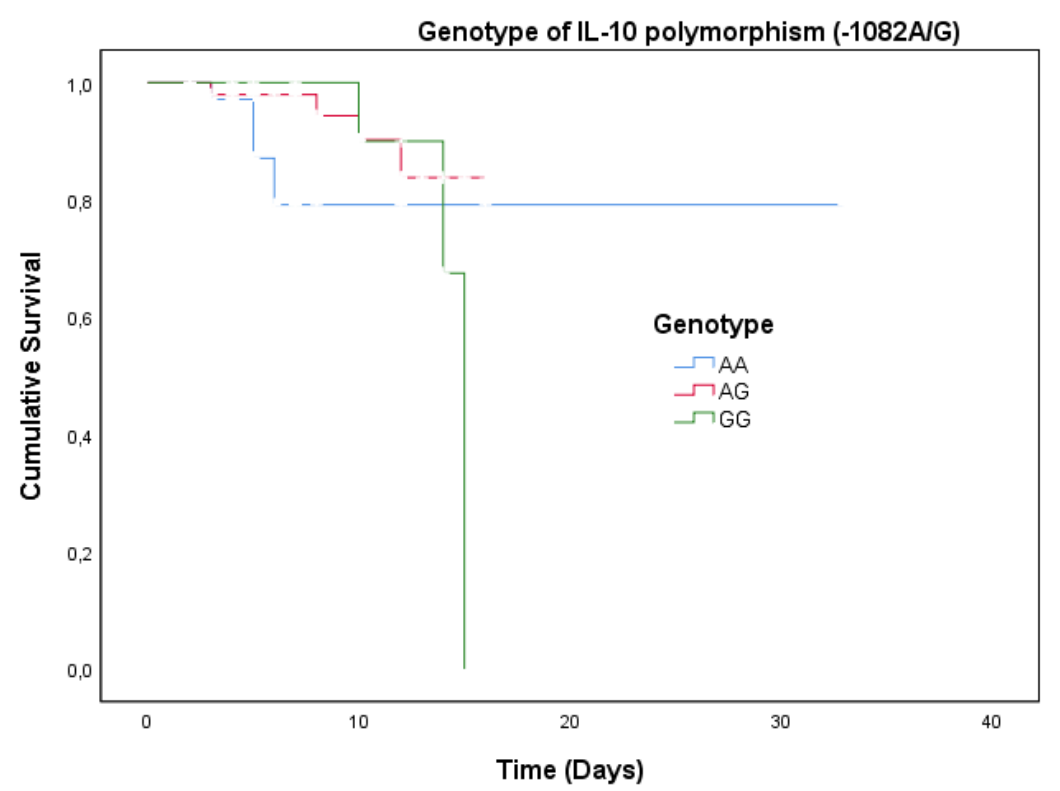

Figure 2. Kaplan-Meier curves showing the cumulative proportion of surviving patients according to the presence of AA vs. other genotypes (AG or GG) of IL-10 promoter polymorphism $(-1082 \mathrm{~A} / \mathrm{G})$.

We hypothesize that elevated levels of IL-10 detected in AA homozygous individuals could induce a state of functional immunoparalysis, triggering an uncontrollable infection, as suggested by Abe et al. [16].

Our results indicate that AA homozygous patients had a higher risk of being infected with Gram negative bacteria $(\mathrm{OR}=2.875 ; 95 \% \mathrm{CI}$ : $1.162-7.113 ; \mathrm{p}=0.02$ ), and the most common source was lung, as has been observed in a number of other studies [17-19]. Steinhauser et al. demonstrated in their study with murine models that the septic response impairs lung innate immunity to Gramnegative bacilli, and this effect is mediated primarily by increase in IL-10 levels [20].

The results of this study indicate that the susceptibility of the patient to infection should be an important factor to be considered, especially in patients with the AA genotype in IL-10 promoter polymorphism $(-1082 \mathrm{~A} / \mathrm{G})$. While individuals with the $\mathrm{G}$ allele is associated with lower IL-10 production being a protective factor. Contrary, Stanilova et al. reported that carriage of the $\mathrm{G}$ allele is associated with higher IL-10 production and increased mortality in severe sepsis [7]. Several studies indicate that GG genotype is associated with increased IL-10 production $[4,7]$.
The discrepancy between study findings could be due to differences in factors such as ethnicity. The meta-analysis performed by Pan et al. reported that IL-10 polymorphisms are associated with susceptibility to sepsis but in Asian populations, because the results in Caucasian populations were inconclusive [13]. Our data show that AA homozygous patients with high plasma IL-10 levels have greater risk of developing sepsis $(\mathrm{OR}=4.894 ; 95 \% \mathrm{CI}$ : 1,337-17.909; $p=0.002$ ), especially Afro-Colombian individuals $(\mathrm{OR}=1.661 ; 95 \%$ CI: $1.408-1.959$; $\mathrm{p}=0.036$ ).

As suggested by Pan et al. [13], it appears that IL-10 promoter polymorphism $(-1082 \mathrm{~A} / \mathrm{G})$ has a race-specific effect in the association between sepsis susceptibility in different ethnicities.

\section{Limitations}

Our sample size is relatively small and may influence the analysis of multivariate logistic model. The determination of other genetic polymorphisms in the IL-10 gene and in other cytokines (such as tumor necrosis factor, IL-1, IL-6) might be relevant for to establish the critical state of the patient [21]. 
On the other hand, no data was provided on the treatments and the response to treatment over time.

\section{CONCLUSION}

An interesting finding was the association between IL-10 promoter polymorphism $(-1082 \mathrm{~A} / \mathrm{G})$ and plasma levels of IL-10.
The present study showed that plasma level of IL-10 is significantly higher in sepsis patients with AA homozygous genotype, especially in AfroColombian individuals. This would indicate that these individuals are more susceptible to dysregulation of IL-10 and enhanced immunopathology infection; however, this polymorphism was not related to the survival of septic patients.

Introducere. IL-10 este o citokină multifuncțională cu rol cheie în patogeneza sepsisului. Am examinat asocierea dintre un polimorfism (SNP) al IL-10-1082G/A la pacienții cu sepsis din Cali.

Metode. Au fost recrutați 100 de pacienți cu sepsis și 50 de martori sănătoși. Nivelurile IL-10 au fost măsurate prin ELISA, iar polimorfismul IL-10 prin tehnica SS-PCR.

Rezultate. Genotipul homozigot AA a fost găsit mai frecvent la pacienți, comparativ cu martori sănătoși (32\% versus $18 \%)$. Prezența acestui genotip s-a asociat cu dezvoltarea infecțiilor cu bacterii Gram negative $(O R=2875 ; 95 \%$ $C I=1$ 162-7 113; $p=0$ 020) și cu niveluri crescute ale $I L-10(O R=4800,95 \%$ CI 1 652-13 944; $p=0$ 002). Pacienții homozigoți AA și cu nivelurile crescute IL-10 au avut un risc mai mare să dezvolte sepsis (63,6\%; OR = 4 894; 95\% CI: $1337-17909 ; p=0,002)$. In acest grup, pacienții afro-columbieni au fost mai degrabă reprezentați printre pacienții cu sepsis și niveluri crescute ale IL-10 $(O R=1661 ; 95 \%$ CI: 1 408-1 959; $p=0,036)$.

Concluzii. Genotipul AA IL-10 -1082 G/A este un factor de risc pentru prezența unor niveluri ridicate de IL-10 și pentru dezvoltarea sepsisului cu bacterii Gram-negative mai ales la pacienții afro-columbieni.

Correspondence to: Monica Chavez Vivas, Ph.D, Department of Biomedical Sciences, Faculty of Health, Universidad Santiago de Cali, Campus Pampalinda, Calle 5 \# 62-00, Cali, Colombia.

Tel: 3217892158 .

E-mail: moikchavez@gmail.com

Acknowledgments: The authors thank the Directorate General for Research (DGI) of Universidad Santiago de Cali [DGI-COCCEIN No.450-621717-005] for funding this study.

Conflict of interest disclosure: The authors have no conflict to interests to declare.

\section{REFERENCES}

1. HJUler T., POUlSEN G., WOHLFAhrT J., KAltOFT M., BIGGAR RJ., MELBYE M. Genetic Susceptibility to Severe Infection in Families with Invasive Pneumococcal Disease. Am J Epidemiol. 2008; 167(7):814-819.

2. WIERSINGA WJ., LEOPOLD SJ., CRANENDONK DR., VAN DER POLL T. Host innate immune responses to sepsis. Virulence. 2014; 5(1):36-44.

3. BOZZA F., SALLUH J., JAPIASSU A., SOARES M., ASSIS E., GOMES R., et al. Cytokine profiles as markers of disease severity in sepsis: a multiplex analysis. Crit Care. 2007; 11:R49.

4. STANILOVA SA. Functional relevance of IL-10 promoter polymorphisms for sepsis development. Crit Care. 2010; 14(1):119.

5. OUYANG L., LV YD., HOU C., WU GB., HE ZH. Quantitative analysis of the association between interleukin-10 1082A/G polymorphism and susceptibility to sepsis. Mol Biol Rep. 2013; 40(7): 4327-4332.

6. ZENG L., GU W., CHEN K., JIANG D., ZHANG L., DU D., et al. Clinical relevance of the interleukin 10 promoter polymorphisms in Chinese Han patients with major trauma: genetic association studies. Crit Care. 2009, 13:R188.

7. STANILOVA SA., MITEVA LD., KARAKOLEV ZT., STEFANOV CS. Interleukin-10-1082 promoter polymorphism in association whith cytokine production and sepsis susceptibility. Intensive Care Med. 2006; 32(2): 260-266.

8. SHU Q., FANG X., CHEN Q., STUBER F. IL-10 polymorphism is associated with increased incidence of severe sepsis. Chin Med J (Engl). 2003; 116(11):1756-1759. 
9. FAIX JD. Biomarkers of sepsis. Crit Rev Clin Lab Sci .2013; 50(1): 23-36.

10. SCHAAF BM., BOEHMKE F., ESNAASHARI H., SEITZER U., KOTHE H., MAASS M., et al. Pneumococcal septic shock is associated with the interleukin-10-1082 gene promoter polymorphism. Am J Respir Crit Care Med. 2003; 168(4): 476-480.

11. SINGER M., DEUTSCHMAN CS., SEYMOUR C., SHANKAR-HARI M., ANNANE D., BAUER MICHAEL., et al. The Third International Consensus Definitions for Sepsis and Septic Choque (Sepsis-3). JAMA. 2016; 315(8):801-810.

12. SCHULTE W., BERNHAGEN J., BUCALA R. Cytokines in sepsis: potent immunoregulators and potential therapeutic targets an updated view. Mediators Inflamm. 2013; 2013:165974.

13. PAN W., ZHANG AQ., YUE CL., GAO JW., ZENG L., GU W., et al. Association between interleukin-10 polymorphisms and sepsis: a meta-analysis. Epidemiol Infect. 2015; 143(2): 366-375.

14. REINHART K. BAUER M., RIEDEMANN NC., HARTOG CS. New approaches to sepsis: molecular diagnostics and biomarkers. Clin Microbiol Rev. 2012; 25(4): 609-634.

15. KANG X., KIM HJ., RAMIREZ M., SALAMEH S., MA X. The septic shock-associated IL-10-1082 A>G polymorphism mediates allele-specific transcription via poly (ADP-Ribose) polymerase 1 in macrophages engulfing apoptotic cells. $\mathrm{J}$ Immunol. 2010; 184(7): 3718-3724.

16. ABE R., HIRASAWA H., ODA S., SADAHIRO T., NAKAMURA M., WATANABE E., et al., Up-regulation of interleukin-10 $m R N A$ expression in peripheral leukocytes predicts poor outcome and diminished human leukocyte antigen-DR expression on monocytes in septic patients. J Surg Res. 2008; 147(1): 1-8.

17. SLIGL WI., DRAGAN T., SMITH SW. Nosocomial Gram-negative bacteremia in intensive care: epidemiology, antimicrobial susceptibilities, and outcomes. Int J Inf Dis. 2015; 37: 129-134.

18. PITTET D, LI N, WOOLSON RF, WENZEL RP. Microbiological factors influencing the outcome of nosocomial bloodstream infections: a 6-year validated, populationbased model. Clin Infect Dis 1997; 24: 1068-78.

19. SLIGL WI., DRAGAN T., SMITH SW. Nosocomial Gram-negative bacteremia in intensive care: epidemiology, antimicrobial susceptibilities, and outcomes. Int J Inf Dis. 2015; 37: 129-134.

20. STEINHAUSER ML., HOGABOAM CM., KUNKEL SL., LUKACS NW., STRIETER ROBERT M., et al. IL-10 Is a Major Mediator of Sepsis-Induced Impairment in Lung Antibacterial Host Defense. J. Immunol., 1999; 162: 392-399.

21. ACCARDO PALUMBO A., FORTE GI., PILERI D., VACCARINO L., CONTE F., D'AMELIO L., et al. Analysis of IL-6, IL-10 and IL-17 genetic polymorphisms as risk factors for sepsis development in burned patients. Burns 2012, 38, $208-213$.

Received $2^{\text {nd }}$ July 2020 